Accepted: 25/01/2021, Reviewed: 07/05/2021, Published: 31/10/2021

\title{
CEREAL FLAKES FROM Ipomoea batatas AND Setaria italica AS EMERGENCY FOOD: CHEMICAL, MICROBIOLOGICAL, AND SENSORY PROPERTIES DURING STORAGE
}

\author{
Ratna Ariani Nilateja Putri, Alia Rahmi, dan Agung Nugroho* \\ Department of Agro-industrial Technology, Faculty of Agriculture, \\ Lambung Mangkurat University, Jl. A. Yani Km. 36, Banjarbaru, Kalimantan Selatan, 70714 \\ ${ }^{*}$ Corresponding Author, Email: anugroho@ulm.ac.id
}

\begin{abstract}
Emergency food supplies the daily human energy needs during emergencies. This research aimed to determine the effects of storage periode of cereal flakes made from sweet potatoes (Ipomoea batatas) and foxtail millet (Setaria italica) on the chemical, microbiological, and sensory properties. The composition of cereal flakes used was $75 \%$ of sweet potato flour and $25 \%$ of jewawut flour. Cereal flakes were tested for proximate levels (moisture, ash, protein, fat, and carbohydrate), crude fiber content, TPC, and sensory. The change observed after 40 days storage at $40^{\circ} \mathrm{C}$ and $\mathrm{RH} 70 \%$ were $0.61-2.51 \%$ in moisture content, $2.29-1.91 \%$ in ash content, $7.44-7.19 \%$ in protein content, $18.79-18.09 \%$ in fat content, $70.88-70.40 \%$ in carbohydrate content, $5.28-4.98 \%$ in crude fiber content, and TPC $5.5 \times 10^{1}-3.1 \times 10^{3} \mathrm{cfu} / \mathrm{g}$. Forty days observation showed that cereal flakes remained in good quality for consumption based on SNI 01-4270-1996. The product is adequate as an alternative of emergency food.
\end{abstract}

Keywords: Emergency food, Cereal flakes, Ipomoea batatas, Setaria italica

\section{INTRODUCTION}

Emergency food is an alternative food solution provided for those who are affected by disaster, the food is expected to help fulfill their basic nutrition needs. Some of the requirements of emergency food are having sufficient nutritional value, being practical and easy to distribute, acceptable to adults and children, fulfilling in terms of calories load, and have a long shelf-life. Usually, the food needed during or in the aftermath of a disaster is in RTE (Ready to Eat) condition, which is practical, ready-to-eat, and contains enough energy, carbohydrate, protein, fat, and other essential nutrition (Almasyhuri et al., 2012). One of the RTE foods suitable for emergency food is cereal flakes.

Cereal flakes are an RTE food that is now starting to replace rice for Indonesians as breakfast. Cereals are generally preferred because of their sweet taste and deliciousness when mixed with milk. In addition, cereals are also quite popular because of their practical processing and can be stored for a long time (Sukasih \& Setyadjit, 2012).

Nagara sweet potato (Ipomoea batatas L.) is a type of sweet potato typical of South Kalimantan which grows in lowland swamps. Sweet potato has a larger tuber size, fluffier texture, high productivity, and high economic value. Pattikawa et al.,(2012) stated that there are many nutrients in sweet potatoes, namely energy, vitamin A, vitamin $C$, and mineral content such as calcium, iron, phosphorus, and fiber. Sweet potato has great potential as a functional food ingredient in the form of flour and starch (Tomlins et al., 2012).

Jewawut (Setaria italica L.) is a cereal foxtail millet (Soeka \& Sulistiani., 2016) that is mostly processed to produce bird feed. Despite being less popular as a food source, jewawut can be processed into food. Furthermore, the processing can be done by the community to support food security and anticipate hunger problems as well as emergency food. Jewawut is a carbohydrate source, rich in vitamins and minerals (Yang et al., 2012). In addition, jewawut also contains antioxidants, bioactive compounds, and high fiber such as cellulose, 
hemicellulose, glycoproteins, and phenolic esters (Thapliyal \& Singh, 2015). Similar to nagara sweet potato, it has the potential to become a functional food. The processing of jewawut in the form of flour makes it versatile for application and has a longer shelf life (Sulistyaningrum, A., Rahmawati \& Aqil, 2017). Based on nagara sweet potato and jewawut processing potentials and nutrient contents, it is worth studying the effect of storage on nagara sweet potato and jewawut cereal flakes on chemical, microbiological, and sensory properties in the effort to investigate its potential as emergency food.

\section{MATERIALS AND METHODS}

\section{Materials and Equipment}

Nagara sweet potato (Ipomoea batatas), jewawut (Setaria italica), sugar, salt, butter, and vanilla were used as ingredients for production of cereal flakes. All of those materials were purchased from the central market in Banjarbaru City. The chemicals for analysis were $\mathrm{H}_{2} \mathrm{SO}_{4}$, $\mathrm{HCl}, \mathrm{NaOH}$, ethanol, and hexane (Merck, Germany). The equipment used includes a blender (Phillips), 80-mesh laboratory sieve (ASTM standard), desiccators, Soxhlets unit, Kjeldahl unit, autoclave (All American), condensers, furnace, analytical balance, incubators and oven (Memmert).

\section{Design of Experiment}

Analysis of the effect of storage on chemical, microbiological, and sensory properties was carried out to determine the characteristics of the cereal flakes made from nagara sweet potato flour and jewawut flour. Based on previous research, Putri et al., (2020) studied cereal flakes formulations using three levels of combination, namely $25 \%$ sweet potato and $75 \%$ jewawut, $50 \%$ sweet potato and $50 \%$ jewawut, and $75 \%$ sweet potato and $25 \%$ jewawut using a completely randomized design. From this research, the best result was obtained from $75 \%$ sweet potato and $25 \%$ jewawut cereal flakes and thus, this formula was further investigated on its storage stability.

\section{Research Stages}

The processing of nagara sweet potato and jewawut cereal flakes started with the production of sweet potato flour, the production of jewawut flour, the formulation of cereal flakes, and the production of cereal flakes. Cereal flakes were packed in aluminum foil packaging which is then stored in an incubator at $40^{\circ} \mathrm{C}$ and $70 \% \mathrm{RH}$ for 40 days of observation for their chemical, microbiological, and sensory properties. Throughout the shelf-life observation, moisture content was observed every 5 days, the ash content, protein content, fat content, carbohydrate content, and crude fiber content were observed every 10 days, while TPC was observed every 20 days.

\section{Methods}

Cereal flakes were made by mixing additional ingredients with predetermined formulations. The dough was then flattened and sliced to form the desired cereal flakes. The flat slices were baked at $150{ }^{\circ} \mathrm{C}$ for 15 minutes. The final products were packed in aluminum foil packaging.

\section{Analysis Procedure}

The parameters tested included moisture content using thermogravimetric method (SNI, 1992), ash content using the dry method, protein content using micro Kjeldahl method (SNI, 1992), fat content using Soxhlet extraction method (SNI, 1992), carbohydrate content using by difference method, crude fiber content using hydrolysis method (SNI, 1992), Total Plate Count (TPC) using pour plate method (Yunita et al., 2015), and sensory tests using scoring and hedonic tests.

Sensory aspects were tested on taste, color, texture, and aroma. The scoring and hedonic tests were performed by 25 panelists using 5 -scale values and 7-scale values, respectively. Taste scoring test scales were: 1 (very bitter), 2 (bitter), 3 (slightly sweet), 4 (sweet), and 5 (very sweet). Color scoring test scales were: 1 (brownish white), 2 (brownish 
yellow), 3 (light brown), 4 (brown), and 5 (dark brown). Texture scoring test scale was: 1 (very not crunchy), 2 (not crunchy), 3 (slightly crunchy), 4 (crunchy), and 5 (very crunchy). The aroma scoring test scale was: 1 (rancid), 2 (slightly rancid), 3 (not aromatic), 4 (typical cereal aroma), and 5 (strong typical cereal aroma). Hedonic test scale was: 1 (very dislike), 2 (very dislike), 3 (dislike), 4 (no opinion (neither like nor dislike)), 5 (like), 6 (really like), and 7 (very much). A Hedonic test was performed against taste, color, texture, and aroma.

Chemical test data were analyzed using the ANOVA test $(P=0.05)$ and followed by the DMRT test $(P=0.05)$, while the sensory test used Kruskal Wallis $(P=0.05)$ and followed by the Post Hoc Test $(P=0.05)$.

\section{RESULTS AND DISCUSSION}

\section{Product Properties during Storage}

Microbiological and chemical properties including proximate and crude fibers contents of the product were evaluated during 40 days storage. As shown in Table 1 and Table 2, the moisture increased gradually from $0.61 \%$ on the start day to $2.51 \%$ on day 40 . Statistically, during 40 days storage the escalation of the products' moisture was significant although the values were still under the SNI standard (max. 3.0). High level of the storage room humidity $(83 \%)$ and the selected packaging system may contribute to the migration of water vapor from the environment to the product. Alumunium foil pouches with zipper lock may not be strong enough to keep the product against water vapor absorption. The locking system of the alumunium foil pouch should be combined with a heat sealing mechanism for better isolation system.

Table 1. Chemical and microbiological properties (40 days storage)

\begin{tabular}{|c|c|c|c|c|c|c|c|c|c|c|}
\hline Parameters & $\mathrm{D}_{0}$ & $D_{5}$ & $D_{10}$ & $D_{15}$ & $D_{20}$ & $D_{25}$ & $\mathbf{D}_{30}$ & $\mathbf{D}_{35}$ & $D_{40}$ & $\begin{array}{c}\text { SNI 01-4270- } \\
1996\end{array}$ \\
\hline Moisture (\%) & $0.61^{a}$ & $\underset{b}{0.75^{a}}$ & $0.97^{b}$ & $1.00^{b}$ & $1.36^{c}$ & $\begin{array}{l}1.7 \\
2^{d}\end{array}$ & $2.18^{e}$ & $2.41^{f}$ & $2.51^{\text {ef }}$ & Max. 3.0 \\
\hline Ash (\%) & $2.29^{b}$ & - & $2.27^{b}$ & - & $2.08^{\mathrm{ab}}$ & - & $2.10^{\mathrm{ab}}$ & - & $1.91^{\mathrm{a}}$ & Max. 4.0 \\
\hline Protein (\%) & $7.44^{\mathrm{ab}}$ & - & $7.85^{\mathrm{b}}$ & - & $7.53^{\mathrm{ab}}$ & - & $7.05 a$ & - & $7.19^{a b}$ & Min. 5.0 \\
\hline Lipid (\%) & $18.79^{c}$ & - & $18.52^{b}$ & - & $18.30^{\mathrm{ab}}$ & - & $18.07^{a}$ & - & $18.09^{a}$ & Min. 7.0 \\
\hline $\begin{array}{l}\text { Carbohydrate } \\
(\%)\end{array}$ & $70.88^{a}$ & - & $70.40^{a}$ & - & $70.66^{a}$ & - & $70.60^{a}$ & - & $70.40^{a}$ & Min. 60.0 \\
\hline $\begin{array}{l}\text { Crude fibers } \\
(\%)\end{array}$ & $5.28^{a}$ & - & $5.46^{a}$ & - & $5.42^{a}$ & - & $5.26^{a}$ & - & $4.98^{a}$ & Max. 0.7 \\
\hline
\end{tabular}

TPC (cfu/g) $5.5 \times 10^{1 \mathrm{a}} \quad-\quad-\quad \quad-\quad 5.2 \times 10^{2 \mathrm{a}} \quad-\quad-\quad-3.1 \times 10^{3 \mathrm{~b}}$ Max. $5.0 \times 10^{5}$ Note: different superscript letters indicate significantly different results between days.

Table 2. Regression equations and $R^{2}$ values for chemical and microbiological properties (40 days storage)

\begin{tabular}{llc}
\hline Parameters & Regression Equations & $\mathbf{R}^{2}$ Values \\
\hline Moisture (\%) & $y=0.0524 x+0.4522$ & 0.9651 \\
Ash (\%) & $y=-0.0092 x+2.3106$ & 0.8901 \\
Protein (\%) & $y=0.0001 x^{3}-0.0072 x 2+7.4367$ & 0.9987 \\
Lipid (\%) & $y=-0.0184 x+18.721$ & 0.9197 \\
Carbohydrate (\%) & $y=-7 E-05 x^{3}+0.0046 x^{2}-0.0781 x+70.86$ & 0.8569 \\
Crude fibers (\%) & $y=9 E-06 x 3-0.0013 x^{2}+0.029 x+5.2816$ & 0.9980 \\
TPC (cfu/g) & $y=74.875 x-289.17$ & 0.8632 \\
\hline
\end{tabular}

The ash content throughout 40 days of storage ranged from 2.29 to $1.91 \%$, where the highest ash content was on day $0(2.29 \%)$ and the lowest was on day $40(1.91 \%)$, which means that the ash content has decreased. This decrease could be due to an increase in water content, where the water 
content is inversely proportional to the ash content so that when the water content increases, the ash content will decrease (Riansyah et al., 2013). From the results of the ash content, the cereal flakes cereal is still following with SNI 01-4270-1996, maximum 4.0\%, after 40 days storage.

The protein content of cereal flakes throughout 40 days storage ranged from $7.05-7.85 \%$. The highest protein content was on day 10 (7.85\%) and the lowest was on day 30 (7.05\%), which means that protein levels have decreased. This decrease could be due to the denaturation of proteins during storage in the incubator at $40^{\circ} \mathrm{C}$ (Dari et al., 2020). From the results of the protein content, the cereal flakes exceeded SNI 01-4270-1996 requirement for cereals (at least 5.0\%).

The fat content over 40 days of storage ranged from $18.07-18.79 \%$. The highest fat content was on day $0(18.79 \%)$ and the lowest was on day $30(18.07 \%)$, which means that the fat content has decreased. This decrease was due to the influence of temperature during storage in the incubator $\left(40^{\circ} \mathrm{C}\right)$. The heat may contribute to the hydrolysis of fat to become fatty acids, subsequently, these fatty acids will evaporate or chemically broken down into fat derivatives throughout the course of storage. From the results of the fat content, the cereal flakes comply with SNI 01-4270-1996 for cereals, minimum 7.0\%.

The carbohydrate content of cereal flakes during the shelf-life study ranged from 70.40 $70.88 \%$. The highest carbohydrate content was on day $0(70.88 \%)$ and the lowest was on day 10 and day $40(70.40 \%)$, which means that the carbohydrate content has decreased. This decrease could be due to the increase in other proximate content parameters. Carbohydrate content was calculated using by difference method. Thus, as the other proximate content increases, the carbohydrate content decreases to fit in the $100 \%$ scale. From the results of the carbohydrate content, the cereal flakes cereal complied with SNI 01-4270-1996 for cereals, minimum $60.0 \%$.

The crude fiber content during the 40 days study ranged from 5.46 to $4.98 \%$. The highest crude fiber content was on day $10(5.46 \%)$ and the lowest was on day $40(4.98 \%)$, which means that crude fiber content has decreased. However, based on the results obtained, crude fiber content is not significantly different, so it can be said that there is no significant difference between days in crude fiber content. From the results of the crude fiber content, the cereal flakes exceeded SNI 01 4270-1996 for cereal (maximum 0.7\%). However, the average consumption of crude fiber that the body needs in a day based on the recommendations of the WHO is 25-30 grams (Rahmah et al., 2017). Given the serving portion, the consumption of nagara sweet potato and jewawut cereal flakes will not exceed WHO recommendation. It can be a good source of crude fiber and may have potential as functional food cereal flakes.

TPC increased throughout the 40 days observation, from $5.5 \times 10^{1}$ to $3.1 \times 10^{3} \mathrm{cfu} / \mathrm{g}$. The highest TPC was on day $40\left(3.1 \times 10^{3} \mathrm{cfu} / \mathrm{g}\right)$ and the lowest was on day $0\left(5,5 \times 10^{1} \mathrm{cfu} / \mathrm{g}\right)$. The increase is due to the condition of storage which included high temperature and high humidity. The initial microbial load in the sample also affected the increase in the number of microorganisms of the cereal flakes (Sukmawati, 2018). From the TPC results, the cereal flakes still comply with SNI 01-4270-1996 for cereals, max. $5.0 \times 10^{5} \mathrm{cfu} / \mathrm{g}$.

\section{Cereal Flakes Scoring Values during Storage}

The results of a scoring test on taste, color, texture, and aroma are presented in Table 3. Taste score is decreasing by the day, although it still falls in the same sweetness category. The taste of cereal flakes on day 0 to day 40 ranged from 4.34 (sweet) - 4.20 (sweet). The decrease may be attributed to the interaction between components during storage. However, this value indicated that panelists did not detect bitterness in the product both fresh and after 40 days of storage. Hence, the result confirms that the taste of cereal flakes is sweet rather than bitter after a 40 days storage periode.

Cereal flake's color ranged from 4.06 (brown) to 3.76 (light brown) over 40 days observation. The color change could be caused by the increase in moisture content, exposure to air and enzymes, and oxidation reaction which triggered chemical structure changes that are colorrelated (Pajak et al., 2012). The color of the flakes was light brown on day 40 of storage.

Table 3. Scoring test values for taste, color, texture, and aroma (40 days storage)

$\begin{array}{llllll}\text { Parameters } & \mathbf{D}_{0} & \mathbf{D}_{10} & \mathbf{D}_{20} & \mathbf{D}_{30} & \mathbf{D}_{40}\end{array}$




\begin{tabular}{llllll}
\hline Taste & $4.34^{\mathrm{b}}$ & $4.32^{\mathrm{b}}$ & $4.28^{\mathrm{a}}$ & $4.26^{\mathrm{b}}$ & $4.20^{\mathrm{b}}$ \\
Colour & $4.06^{\mathrm{b}}$ & $3.92^{\mathrm{b}}$ & $3.96^{\mathrm{b}}$ & $3.90^{\mathrm{b}}$ & $3.76^{\mathrm{b}}$ \\
Texture & $4.06^{\mathrm{a}}$ & $3.98^{\mathrm{a}}$ & $4.02^{\mathrm{a}}$ & $3.98^{\mathrm{a}}$ & $3.92^{\mathrm{a}}$ \\
Aroma & $4.54^{\mathrm{b}}$ & $4.44^{\mathrm{b}}$ & $4.38^{\mathrm{a}}$ & 4.38 & $4.30^{\mathrm{b}}$ \\
\hline
\end{tabular}

Note: different superscript letters indicate significantly different results between days.

The cereal flake's texture changed over the study period. The texture values ranged from 4.06 (crunchy) on day 0 to 3.92 (slightly crunchy) on day 40 . The crunchiness is related to moisture content. This decrease in texture could be due to increased moisture content. As the moisture content increase throughout the storage period, the texture becomes less crunchy. Ingredients used also play a role in the texture change. The texture of the flakes on day 40 was slightly crunchy.

The cereal flakes maintained their typical cereal aroma, despite the values decreased from day 0 to day 40, from 4.54 (typical cereal aroma) - 4.30 (typical cereal aroma). The Changes in the aroma values could be due to a slight change in volatile compounds which are detectable by the panelists. The cereal flake's aroma is still considered typical cereal products on the $40^{\text {th }}$ day of storage.

\section{Cereal Flakes Hedonic Acceptance during Storage}

The cereal flake's hedonic taste acceptance is decreasing over the observation period (Table 4). It ranged from 5.34 (like) to 4.62 (neither like nor dislike) on day 0 and day 40 . A decrease in the value may be due to the production of aftertaste that is contributed by the interaction of primary ingredients and additives in the cereal flakes throughout the storage period. The taste of flakes is still acceptable for consumption on the $40^{\text {th }}$ day.

Table 4. Hedonic acceptance for taste, color, texture, and aroma (40 days storage)

\begin{tabular}{lccccc}
\hline Parameter & $\mathbf{D}_{0}$ & $\mathbf{D}_{10}$ & $\mathbf{D}_{20}$ & $\mathbf{D}_{30}$ & $\mathbf{D}_{40}$ \\
\hline Taste & $5.34^{\mathrm{c}}$ & $5.32^{\mathrm{b}}$ & $4.90^{\mathrm{a}}$ & $4.74^{\mathrm{a}}$ & $4.62^{\mathrm{a}}$ \\
Colour & $4.64^{\mathrm{a}}$ & $4.66^{\mathrm{a}}$ & $4.68^{\mathrm{a}}$ & $4.62^{\mathrm{a}}$ & $4.54^{\mathrm{a}}$ \\
Texture & $4.76^{\mathrm{a}}$ & $4.74^{\mathrm{a}}$ & $4.72^{\mathrm{a}}$ & $4.64^{\mathrm{a}}$ & $4.58^{\mathrm{a}}$ \\
Aroma & $5.40^{\mathrm{b}}$ & $4.94^{\mathrm{a}}$ & $4.88^{\mathrm{a}}$ & $4.76^{\mathrm{a}}$ & $4.70^{\mathrm{a}}$ \\
\hline
\end{tabular}

Note: different superscript letters indicate significantly different results between days.

The cereal flake's hedonic color acceptance is decreasing over the 40-day storage period but remains within the same category, ranging from 4.68 (neither like nor dislike) to 4.54 (neither like nor dislike) on day 0 and day 40 . The color of the cereal flakes is brown to light brown according to scoring test results. The preference level of this color for a cereal flake product was assigned at "neither like nor dislike" by panelists. The color of the flakes is still considered acceptable.

The cereal flake's texture hedonic preference remained at "neither like nor dislike" throughout the 40 days. It slightly decreased from 4.76 (neither like nor dislike) to 4.58 (neither like nor dislike) on day 0 and day 40 . The cereal flakes texture was crunchy to slightly crunchy according to scoring test results. The decrease in hedonic value could be due to the reduction of flake's crunchiness approaching the end of the storage period. The texture of the flakes is still considered acceptable.

The cereal flake's hedonic aroma acceptance was reduced from 5.40 (like) - 4.70 (neither like nor dislike) on day 0 and day 40 . Based on scoring test values, the cereal flakes maintained their typical cereal aroma throughout the storage period. But it is important to note that the aroma scoring value did decrease. The reduction in aroma acceptance could be due to the production of slightly off-odor compounds which could be attributed to the fat derivatives. Fat derivatives production is reflected through the decrease in fat content during storage. The aroma of the cereal flakes is still acceptable after 40 days of storage.

\section{CONCLUSION}


After a 40-day observation, nagara sweet potato and jewawut cereal flakes were still acceptable for consumption as the product still complies with the quality requirements demanded by SNI 01-4270-1996 for cereal. On the $40^{\text {th }}$ day of the storage period, nagara sweet potato and jewawut cereal flakes had a moisture content of $2.41 \%$, ash content of $1.91 \%$, protein content of $7.19 \%$, fat content of $18.09 \%$, carbohydrate content of $70.40 \%$, crude fiber content of $4.98 \%$, TPC of $3.1 \times 10^{3} \mathrm{cfu} / \mathrm{g}$, and sensory tests (scoring and hedonic) that were still suitable for consumption.

\section{ACKNOWLEDGMENTS}

The authors thank PT. Indoofood CBP Sukses Makmur Tbk. for financial support for this work through Indofood Riset Nugraha.

\section{REFERENCES}

Almasyhuri, Imanningsih, N., \& Yuniati, H. (2012). Formulasi Biskuit Padat untuk Makanan Darurat. Penel Gizi Makan. Penelitian Glzi Dan Makanan, 35(1), 42-58.

Mutu dan Cara Uji Biskuit, Pub. L. No. SNI 01-2973 (1992).

Dari, D. W., Ananda, M., \& Junita, D. (2020). Karakteristik Kimia Sari Buah Pedada (Sonneratia caseolaris) Selama Penyimpanan. Jurnal Teknologi Pertanian Andalas, 24(2), 189-195.

Pajak, P., Habryka, C., \& Fortuna, T. (2012). Changes in The Physical Properties of Bread During Storage. Potravinarstvo, 6(2), 42-45.

Pattikawa, A. B., Suparno, A., \& Prabawardani, S. (2012). Analisis Nutrisi Umbi Ubi Jalar (Ipomoea batatas (L.) Lam.) untuk Konsumsi Bayi dan Anak-Anak Suku Dani di Distrik Kurulu Kabupaten Jayawijaya. Jurnal Agrotek, 3(2), 32-36.

Putri, R. A., Rahmi, A., \& Nugroho, A. (2020). Karakteristik Kimia, Mikrobiologi, Sensori Sereal Flakes Berbahan Dasar Tepung Ubi Nagara (Ipomoea batatas L.) dan Tepung Jewawut (Setaria italica). Jurnal Teknology Agro-Industry, 7(1), 1-11.

Rahmah, A. D., Rezal, F., \& Rasma. (2017). Perilaku Konsumsi Serat pada Mahasiswa Angkatan 2013 Fakultas Kesehatan Masyarakat Universitas Halu Oleo Tahun 2017. Jurnal IImiah Mahasiswa Kesehatan Masyarakat, 2(6), 1-10.

Riansyah, A., Supriadi, A., \& Nopianti, R. (2013). No TitlePengaruh Perbedaan Suhu dan Waktu Pengeringan Terhadap Karakteristik Ikan Asin Sepat Siam (Trichogaster pectoralis) dengan Menggunakan Oven. Jurnal FishtecH, 2(1), 53-68.

Soeka, Y. S., \& Sulistiani. (2016). Profil Vitamin, Kalsium, Asam Amino dan Asam Lemak Tepung Jewawut (Setaria italica L.) Fermentasi. Jurnal Biologi Indonesia, 13(1), 85-96.

Sukasih, E., \& Setyadjit. (2012). Formulasi Pembuatan Flake Berbasis Talas untuk Makanan Sarapan (Breakfast Meal) Energi Tinggi dengan Metode Oven. Jurnal Pascapanen, 9(2), 70-76.

Sukmawati. (2018). Total Microbial Plates on Beef and Beef Offal. Bioscience, 2(1), 22-28.

Sulistyaningrum, A., Rahmawati, \& Aqil, M. (2017). ). Karakteristik Tepung Jewawut (Foxtail Millet) Varietas Lokal Majene Dengan Perlakuan Perendaman. Jurnal Penelitian Pascapanen Pertanian,. Jurnal Penelitian Pascapanen Pertanian, 14(1), 11-21.

Thapliyal, V., \& Singh, K. (2015). No TitleFinger Millet: Potential Millet for Food Security and power House of Nutrients. International Journal of Research in Agriculture and Forestry, 2(2), 22-23.

Tomlins, K., Owori, C., Bechoff, A., Menya, G., \& Westby, A. (2012). Relationship Among The Carotenoid Content, Dry Matter Content and Sensory Attributes of Sweet Potato. Food Chemistry, 131(1), 14-21.

Yang, X., Wan, Z., Perry, L., Lu, H., Wang, Q., Zhao, C., \& Ge, Q. (2012). ). Early Millet Use in Northern China. Proceedings of the National Academy of Sciences of the United States of America, 3726-3730.

Yunita, M., Hendrawan, Y., \& Yulianingsih, R. (2015). Analisis Kuantitatif Mikrobiologi pada Makanan Penerbangan (Aerofood ACS) Garuda Indonesia Berdasarkan TPC (Total Plate Count) dengan Metode Pour Plate. Jurnal Keteknikan Pertanian Tropis Dan Biosistem, 3(3), 237-248. 